\title{
Effect of seasonal mesoscale and microscale meteorological conditions in Ny-Ålesund on results of monitoring of long-range transported pollution
}

\author{
Alena Dekhtyareva (D) ${ }^{a}$, Kim Holmén ${ }^{b}$, Marion Maturilli ${ }^{c}{ }^{c}$, Ove Hermansen ${ }^{d}$ \& Rune Graversen ${ }^{\mathrm{e}}$ \\ aDepartment of Engineering and Safety, Faculty of Engineering and Technology, UiT-The Arctic University of Norway, Tromsø, Norway; \\ ${ }^{b}$ Norwegian Polar Institute, Longyearbyen, Norway; 'Climate Sciences Department, Alfred Wegener Institute Helmholtz Centre for Polar

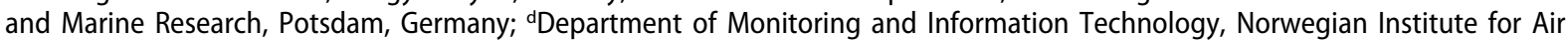

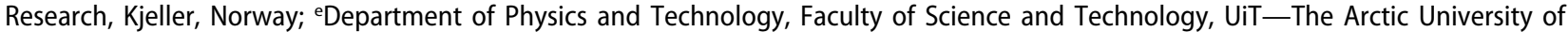 \\ Norway, Tromsø, Norway
}

\begin{abstract}
Ny-Ålesund is an international research settlement where the thermodynamics and chemical composition of the air are monitored. The present work investigates the effects of micrometeorological conditions, mesoscale dynamics and local air pollution on the data collected at two different locations around the village. Daily filter measurements of sulphur dioxide and non-sea salt sulphate from the temporary Ny-Ålesund station and permanent Zeppelin mountain station have been analysed along with meteorological data. The influence of different factors representing micrometeorological phenomena and local pollution from ships has been statistically investigated. Seasonal variation of the correlation between the data from Ny-Ålesund and Zeppelin stations is revealed, and the seasonal dependence of the relative contribution of different factors has been analysed. The median concentrations of $\mathrm{SO}_{4}{ }^{2-}$ measured in Ny-Ålesund increased significantly on days with temperature inversions in winter. In spring, concentrations of $\mathrm{SO}_{2}$ and $\mathrm{SO}_{4}{ }^{2-}$ were higher than normal at both stations on days with temperature inversions, but lower on days with strong humidity inversions. In summer, local ship traffic affects the $\mathrm{SO}_{2}$ data set from Ny-Ålesund, while no statistically significant influence on the Zeppelin data set has been observed. The pollution from ships has an effect on $\mathrm{SO}_{4}{ }^{2-}$ values at both stations; however, the concentrations in Ny-Ålesund were higher when local pollution accumulated close to the ground in days with strong humidity inversions.
\end{abstract}

\section{KEYWORDS}

Micrometeorology; air pollution; Arctic haze; atmospheric inversion; aerosol; sulphate

\section{ABBREVIATIONS}

ABL: atmospheric boundary layer; DMS: dimethyl sulphide; WRS: Wilcoxon rank sum

\section{Introduction}

A small community on the north-west Coast of Spitsbergen island, in the Svalbard Archipelago, NyÅlesund is a place for fruitful international cooperation in connection with environmental monitoring. Data and knowledge exchange between researchers from 12 different nations leads to joint publications and improves our scientific understanding of various processes in a rapidly changing Arctic (Norwegian Polar Institute 2016). Specific attention is given to the study of the Arctic haze phenomena, aerosol of anthropogenic origin enriched in non-sea salt sulphate $\left(\mathrm{XSO}_{4}{ }^{2-}\right)$ and transported over long distances from mid-latitudes to the Arctic during winter and spring (Quinn et al. 2007; Dekhtyareva et al. 2016; Ferrero et al. 2016). Ny-Ålesund is situated far from major industrial areas, and is therefore considered suitable for monitoring of long-range transported pollution. This study considers whether the data collected at different locations around the village show differences due to local environmental peculiarities of this site.
The settlement is in a mountainous coastal area near the narrow fjord Kongsfjorden, which has two glaciers at the one end and the Greenland Sea at the other (Fig. 1a). Thermally driven circulations, such as katabatic winds and sea-land breeze, channelling of mesoscale wind along the fjord and the shielding effect of surrounding mountains, are local topographically induced features (Esau \& Repina 2012; Maturilli et al. 2013; Maturilli \& Kayser 2016). Wind shear and turbulence, affecting the mixing and dilution of air pollutants, may be induced or suppressed by these features (Fisher 2002). Furthermore, temperature and humidity inversions often occur in the ABL as a result of surface cooling during winter and spring and are frequently observed in Svalbard (Vihma et al. 2011). Mixing processes are limited in the stable ABL. This leads to variation in humidity with altitude, and therefore affects the amount of water, condensation processes and particle growth (Stull 1988; Seinfeld \& Pandis 2006). Consequently, different aerosol content appearing at different altitudes have been observed during several 

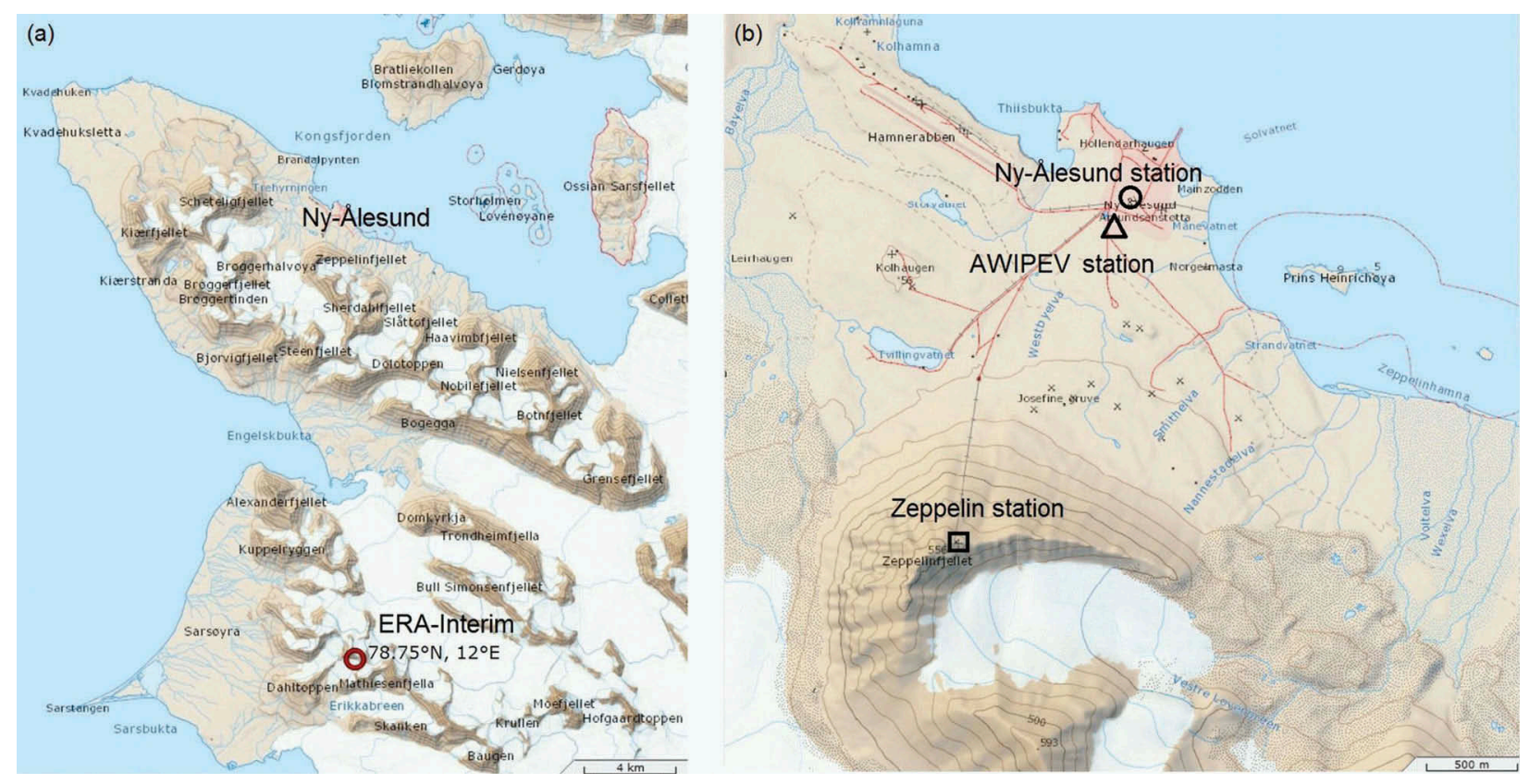

Figure 1. (a) The location of Ny-Ålesund on western Spitsbergen and the ERA-Interim data grid point (circled); (b) map of Ny-Ålesund, indicating the locations of the measurement stations.

field campaigns in Svalbard (Moroni et al. 2015; Ferrero et al. 2016). However, the humidity inversions are not always linked to the temperature inversions and may be associated with the unequal distribution of moisture with height in the air masses advected over the measurement site (Nygård et al. 2014).

Long-range transported pollution is dominant during all seasons of the year except summer, when instead ship traffic has been shown to be a significant local source of pollution (Eckhardt et al. 2013; Dekhtyareva et al. 2016). In summer, the mixing height of the ABL may increase, especially due to radiative heating of the surface leading to convection, and therefore local pollution may be transported aloft (Stull 1988). However, studies of wind climate in Kongsfjorden showed that despite this process, the thickness of local surface winds is lowest in summer, when it is estimated to be around $500 \mathrm{~m}$ (Esau \& Repina 2012). Therefore, it is questionable to what extent convective mixing promotes the even distribution of pollutants within the local ABL. Pollution may also be trapped beneath an inversion layer and accumulate close to the ground, when the air above the measurement site descends and undergoes adiabatic compression and warming. Subsidence inversions may occur in the Arctic troposphere in summer as a response to diabatic heating and convection over land masses in the sub-Arctic $\left(50^{\circ}-55^{\circ} \mathrm{N}\right)$ after the springtime snowmelt (Matsumura et al. 2014). Another source of local pollution in Ny-Ålesund is the small power plant running on low-sulphur diesel year-round (Dekhtyareva et al. 2016). In order to prevent interference of local pollution in the monitoring of background air composition, the Zeppelin Observatory was established $2 \mathrm{~km}$ away from the settlement, on the top of Mount Zeppelin at $474 \mathrm{~m}$ a.s.l. (Fig. 1b; Braathen et al. 1990; Beine et al. 1996).

There is also a local biogenic source of sulphate in Ny-Ålesund. Sulphate is produced from oxidation of DMS, which is emitted by marine plankton (Keller et al. 1989; Seinfeld \& Pandis 2006), and $\mathrm{SO}_{2}$ is an intermediate product of this reaction (Yin et al. 1990). Previous studies have shown that the concentration of chlorophyll $a$ increases in April-May, July and September in Kongsfjorden, suggesting multiple blooms of algae in the fjord (Seuthe et al. 2011). The occurrence of the blooms varies from year to year depending on sea-ice cover, dominating water masses in the fjord and the inflow of freshwater from glaciers and land (Hodal et al. 2012). Although there is a significant positive correlation between algal chlorophyll $\alpha$ and DMS concentration in seawater, the actual DMS concentration depends on the taxonomic composition of the plankton community and trophic interactions within it (Yoch 2002). Because the combination of sunlight and ice-free conditions favours increased DMS emissions, this marine source of biogenic sulphur may be considered significant only in late spring, summer and early autumn (Shikai et al. 2012; Levasseur 2013).

Taking into account these local micrometeorological features and sources of sulphur agents, we address the correlation of the daily concentrations of anthropogenic sulphur compounds measured on filter samples at the Zeppelin station (474 $\mathrm{m}$ a.s.l.) and in Ny-Ålesund 
(8 $\mathrm{m}$ a.s.l.) and their seasonally dependent variations (Fig. 1b).

Chemical and meteorological data were used to test the following hypotheses. (1) Low-level temperature and humidity inversions during winter and spring prevent even mixing of pollutants with height and disturb correspondence between the Ny-Ålesund and Zeppelin station data sets. (2) If the wind direction is dissimilar at the two stations, we expect differences in the concentrations of pollutants as the air sampled at the two sites may have different origins, affecting the correlation between the measurements at sea level and on the mountain top. (3) Wind shear has a significant effect on the dilution of local pollution in the $\mathrm{ABL}$ and reduces differences in the measurements from the two stations. (4) Local summertime ship traffic has a strong impact on the Ny-Ålesund data set and induces deviations from the Zeppelin data set.

\section{Methods}

\section{Study area and materials}

Measurements of two key long-range transported sulphur compounds have been analysed in this work: sulphate, $\mathrm{SO}_{4}{ }^{2-}$ (particulate), and sulphur dioxide, $\mathrm{SO}_{2}$ (gaseous). Daily filter samples were collected in Ny-Ålesund during the Monitoring of Local Air Quality in Ny-Ålesund project from 1 July 2008 until 31 December 2009 (Hermansen et al. 2011). A temporary measurement cabin, hereafter called the $\mathrm{Ny}$ Ålesund station, (Fig. 1b), was installed in the middle of the settlement. Measurement results from the Zeppelin station (Fig. 1b) for the same period are available at the website http://ebas.nilu.no/. The sampling procedure was identical to the one used in the European Monitoring and Evaluation Programme (NILU 1996). No correction of filter sampling volume for temperature and pressure has been done, as only the inlets were placed outside while the measurement equipment was kept indoors at both sites, so the equipment was not subject to changes in the environmental parameters (NILU 1996). Only $\mathrm{SO}_{2}$ and $\mathrm{XSO}_{4}{ }^{2-}$ data have been utilized in the present work. The data owner, the Norwegian Institute for Air Research, has performed a correction for sea salt. This institute also provided hourly temperature, pressure, relative humidity, wind speed and wind direction data obtained at the two stations. Previous studies have shown that the local wind measurements at the Zeppelin station are subject to a wind-shielding effect from nearby mountains, so these data cannot be used for comparison with measurement results from Ny-Ålesund (Dekhtyareva et al. 2016). Therefore, atmospheric stratification and local wind flows in the lowest atmosphere (0-500 m height) were studied using atmospheric radiosoundings performed by the Alfred Wegener Institute in $\mathrm{Ny}$ Ålesund. Wind speed and direction, atmospheric temperature and relative humidity data were retrieved from measurements taken with the Vaisala RS92 radiosonde launched from the French-German AWIPEV station (Fig. 1b; Maturilli \& Kayser 2016). The soundings provided by the Alfred Wegener Institute cover the whole measurement period except for one day, 8 December 2008. For days with more than one sounding available, the profile closest to the 12 UTC standard launch time has been chosen to maintain consistency.

Vihma et al. 2011 studied meteorological data at the pressure level of $850 \mathrm{hPa}$ and at the surface to assess the influence of prevailing mesoscale meteorological situation on local wind flows and vertical stratification in the ABL. Similarly, we have analysed air temperature, specific humidity, wind speed and wind direction at these two vertical levels in Svalbard and at the point closest to the Zeppelin station (Fig. 1a). For this purpose, meteorological values for 12 UTC have been chosen from the global ERAInterim reanalysis data set with a $0.75 \times 0.75$ degrees resolution, and no interpolation has been done (Dee et al. 2011).

\section{Data analysis}

Vertical wind shear is identified as a change in wind direction and/or speed with altitude (Markowski \& Richardson 2006). Directional and speed shears were analysed separately in the study reported here. In order to assess the influence of variation in wind direction with height on correlation between the data sets, the daily measurements for each season were divided into two categories: those with and those without a change in wind direction with height of more than 90 degrees. In each radiosonde profile, all measurement points with wind speed above $2 \mathrm{~ms}^{-1}$ were defined to exclude cases with very weak winds, which may introduce ambiguity in the wind direction data (EPA 2000). Then the wind direction at each point was compared with values at points located higher in the profile, and the lowest height, when wind direction changes by more than 90 degrees, was defined. If this change happened in the lowermost $500 \mathrm{~m}$, then the day was classified as a day with directional wind shear. The simulation done by Walcek (2002) with a vertical wind shear of $2.5 \mathrm{~ms}^{-1} \mathrm{~km}^{-1}$ shows the significant influence of higher wind speed above the surface on reducing the maximum concentrations and horizontal spreading of polluted air masses. Similarly, in our study, the effect of vertical speed shear was investigated by identifying two separate groups: one in which the wind speed increased by $1.25 \mathrm{~ms}^{-1}$ or more per $500 \mathrm{~m}$ height and one where it was not observed. 
Table 1. Meteorological phenomena observed in the radiosonde profiles in different seasons.

\begin{tabular}{|c|c|c|c|c|c|}
\hline \multirow[b]{2}{*}{ Phenomena observed in the lowermost $500 \mathrm{~m}$} & \multirow[b]{2}{*}{ Parameter } & \multicolumn{4}{|c|}{ Season } \\
\hline & & $\begin{array}{l}\text { summer } \\
(n=154)\end{array}$ & $\begin{array}{l}\text { autumn } \\
(\mathrm{n}=182)\end{array}$ & $\begin{array}{c}\text { winter } \\
(n=121)\end{array}$ & $\begin{array}{c}\text { spring } \\
(\mathrm{n}=92)\end{array}$ \\
\hline \multirow[t]{2}{*}{ Temperature inversion } & Frequency of occurrence (\%) & 36 & 51 & 66 & 60 \\
\hline & Median inversion strength TIS $\left({ }^{\circ} \mathrm{C}\right)$ & 0.80 & 0.95 & 0.90 & 1.10 \\
\hline \multirow{2}{*}{ Humidity inversion } & Frequency of occurrence (\%) & 93 & 85 & 77 & 76 \\
\hline & Median inversion strength QIS (g/kg) & 0.22 & 0.10 & 0.07 & 0.09 \\
\hline Both temperature and humidity inversion & Frequency of occurrence (\%) & 35 & 44 & 56 & 48 \\
\hline Low wind speed conditions & Frequency of occurrence (\%) & 50 & 16 & 13 & 23 \\
\hline Low-level cloud & Frequency of occurrence (\%) & 45 & 24 & 19 & 17 \\
\hline
\end{tabular}

To assess whether air in the ABL is well mixed, moisture variation with altitude was estimated using relative humidity, air temperature and pressure retrieved from radiosoundings (Stull 1988). Formulas presented by Bolton (1980) and Wallace \& Hobbs (2006) have been applied to calculate saturated vapour pressure and specific humidity, respectively.

In order to investigate the influence of temperature and humidity inversions on the correlation between the two data sets, a methodology for inversion detection identical to the one described by Vihma et al. (2011) was used. The height and temperature of the inversion base $\mathrm{zTb}$ and $\mathrm{Tb}$, respectively, were defined at the point in the radiosonde vertical temperature profile where temperature begins to increase with height. The height and temperature of the level where temperature starts decreasing with height are defined as $\mathrm{zTt}$ and $\mathrm{Tt}$, respectively. Similarly, using specific humidity profiles, height and humidity values at the humidity inversions' top, $\mathrm{zQt}$ and Qt, and bottom, $\mathrm{zQb}$ and $\mathrm{Qb}$, were found. The temperature and humidity inversion strengths were calculated as the difference of these parameters at the top and bottom levels: TIS and QIS. Following Vihma et al. (2011), temperature and specific humidity changes of more than $0.3^{\circ} \mathrm{C}$ and $0.02 \mathrm{~g} \cdot \mathrm{kg}^{-1}$, respectively, through the levels with depth more than $10 \mathrm{~m}$ were defined as inversions.

The seasonal $\mathrm{SO}_{2}$ and $\mathrm{XSO}_{4}{ }^{2-}$ data sets from the $\mathrm{Ny}$-Ålesund and the Zeppelin stations were divided into groups according to the absence or presence of the factor of interest: directional and wind speed shear, temperature inversion and/or humidity inversion, and local summertime pollution from ships. To assess the influence of these factors on the seasonal concentrations on filter samples from both stations, the WRS test was chosen, because it is more powerful for discrete samples and data from skewed distributions than the t-test (Krzywinski \& Altman 2014). The WRS test checks whether two independent samples, grouped according to a specific factor, come from distributions with equal medians. In other words, if the hypothesis in this test is rejected at the $5 \%$ confidence level $(p<0.05)$, there is a statistically significant difference between the two samples, and the factor on the basis of which the data were grouped is recognized as being important.

Another relevant characteristic affecting the possibility of local pollution reaching the Zeppelin station in summer is the height of the mixed layer in the lowest atmosphere. The mixed layer has low variation in specific humidity, wind speed and wind direction (Stull 1988). According to Chernokulsky et al. (2017), mean total cloud cover for Svalbard is highest in summer and constitutes around $80 \%$. To calculate the mixing height, a method combining information about the lapse rate, vertical variation of water content and mixing within clouds, was applied based on a three-step procedure (Wang \& Wang 2014). First, mixing height $h_{0}$ was defined based on vertical gradients of potential temperature, relative and specific humidity and refractivity. Second, the location of a cloud was identified using relative humidity thresholds specific for altitude range from 0 to $2 \mathrm{~km}$ (table 1 in Wang \& Wang 2014). Third, if a cloud base was lower than $\mathrm{h}_{0}$ and there was a stable layer within the cloud, the consistent mixing layer height $h_{\text {con }}$ was set to the height of the sharpest inversion within this layer. The detailed procedure of determining $h_{\text {con }}$ is described by Wang \& Wang (2014).

\section{Results and discussion}

The seasonal variation of different meteorological phenomena in the lowermost $500 \mathrm{~m}$ is presented in Table 1. Temperature inversions were detected most often in winter, but the highest average temperature inversion strength was observed in spring. The rate of days when both temperature and humidity inversions were present is highest for winter. The strongest specific humidity inversions were detected in summer. In general, similarly to results reported by Nygård et al. (2014), humidity inversions were observed most of days, irrespective of the season. Hence, all days were divided into two groups of similar size within each season: (1) with no humidity inversion and humidity inversion with QIS below or equal to the seasonal median; and (2) with inversions with QIS above the seasonal median. This was done to statistically assess the influence of strong humidity inversions on filter measurements by using these 
groups in the WRS test for $\mathrm{SO}_{2}$ and $\mathrm{XSO}_{4}{ }^{2-}$ data from the $\mathrm{Ny}$-Ålesund and Zeppelin stations. In low wind speed conditions, the dispersion of pollutants is controlled by a meandering horizontal flow and weak sporadic turbulence, and air stagnation may occur (Anfossi et al. 2004). Low wind speed conditions are defined here as when the median wind speed is below $2 \mathrm{~ms}^{-1}$ in the lowest $500 \mathrm{~m}$. The seasonal percentage of profiles with low wind speed conditions was highest in summer and reached its minimum in winter. This may indicate that in summer the measurements are potentially more affected by local processes, while the influence of cyclonic activity and advection is stronger in other seasons (Maturilli et al. 2013). Using the procedure described by Wang and Wang (2014), the cloud location in each radiosonde profile was identified. Low-level clouds were observed in nearly half of all summer days, while they were rarely detected in winter and spring. The frequency of occurrence of the phenomena described above indicate that there is a distinct difference between local micrometeorological conditions in summer and other seasons in Ny-Ålesund.

Figure 2 shows the seasonal data sets of $\mathrm{SO}_{2}$ and $\mathrm{XSO}_{4}{ }^{2-}$ collected at the $\mathrm{Ny}$-Ålesund and Zeppelin stations. Statistically significant positive correlations $(p<0.05)$ of $\mathrm{SO}_{2}$ and $\mathrm{XSO}_{4}{ }^{2-}$ data sets between the stations are observed for all seasons except for summer $\mathrm{SO}_{2}$ data, and values of Pearson correlation coefficient $r$ are shown in each plot of the seasonal data. In order to explain dramatic seasonal variation in correspondence between the data sets from the Ny-Ålesund and Zeppelin stations, the WRS test was applied to $\mathrm{SO}_{2}$ and $\mathrm{XSO}_{4}{ }^{2-}$ data from both stations.

Both $\mathrm{SO}_{2}$ and $\mathrm{XSO}_{4}{ }^{2-}$ data sets show the weakest correlation in summer. According to the WRS test, several factors led to this: strong humidity inversions, insufficient vertical wind speed shear and local pollution from ships (Table 2).

The test results show that only $\mathrm{XSO}_{4}{ }^{2-}$ data from the Ny-Ålesund station had significantly higher median concentration for the days with strong humidity inversions than for the days with normal and no humidity inversion. The mesoscale meteorological situation for the days from both humidity inversion groups is shown in Fig. 3. The location of the isobars shows the area of local high pressure that may be linked to subsidence inversion (Fig. 3a). The mean sea-level pressure for the point closest to the Zeppelin station (Fig. 1a) was higher for the days with strong humidity inversion $(1017 \mathrm{hPa})$ than for the days when strong humidity inversion was absent $(1014 \mathrm{hPa})$. Indeed, there is a weak $(\mathrm{r}=0.19)$, but statistically significant $(p=0.02)$, positive correlation between summer QIS and mean sea-level pressure. The mean wind speed was also lower for the first group (Fig. 3a) than for the second one (Fig. 3b). Meteorological observations at the Ny-Ålesund station show a similar picture as the reanalysis results: easterly winds with very low wind speed $\left(1 \mathrm{~ms}^{-1}\right)$ prevailed during the days with strong humidity inversion. Taking into account the location of the station (Fig. 1b), these winds may bring local pollution from the ships anchored in the fjord and/or biogenic sulphur from Kongsfjorden. The presence of strong specific humidity inversion illustrates that pollutants were unevenly distributed with altitude. At the same time, light winds inhibited their removal from the ABL. This indicates that the air was more localized, and if any pollutants had been emitted close to the ground level, they might have persisted for a while.

The presence of gases that may become particle precursors, and enhanced photochemical oxidation, may lead to new particle formation (Seinfeld \& Pandis 2006). The factor controlling dry deposition of particles is the particle size. Hygroscopic aerosol particles containing $\mathrm{XSO}_{4}{ }^{2-}$ absorb water vapour from the air, dissolve as humidity increases, and saturated droplets form. The diameter of the particles increases abruptly. If humidity increases further, the particle diameter and mass grows, and the particles may eventually be deposited (Orr et al. 1958). Therefore, the strong humidity inversions in summer may have a cleansing effect, decreasing aerosol concentration to the ambient level above the inversion. Indeed, when the strong humidity inversion was located below the level of the Zeppelin station, no effect of the pollution accumulation in the ABL was seen on the Zeppelin sulphate measurements, whereas a statistically significant influence was observed at the $\mathrm{Ny}$-Ålesund station.

According to the test, the directional wind shear is not a statistically significant factor. However, wind speed shear was an important factor decreasing the median concentration of $\mathrm{SO}_{2}$ and $\mathrm{XSO}_{4}{ }^{2-}$ at the $\mathrm{Ny}$ Ålesund station in summer, while no shift of median in the Zeppelin $\mathrm{XSO}_{4}{ }^{2-}$ data was observed (Table 2). $\mathrm{SO}_{2}$ is a moderately soluble gas, therefore oxidation to sulphate and dry deposition are the major pathways for $\mathrm{SO}_{2}$ removal from the troposphere on noncloudy days (Liang \& Jacobson 1999; Seinfeld \& Pandis 2006). The dry deposition velocity depends strongly on wind speed and turbulence strength. Indeed, the concentrations of $\mathrm{SO}_{2}$ and $\mathrm{XSO}_{4}{ }^{2-}$ in Ny-Ålesund were almost two times lower when a vertical wind speed shear was observed. In the absence of wind speed shear, concentrations of both compounds increased dramatically in Ny-Ålesund, while no such effect was observed in the data from the Zeppelin station. Long-term studies based on the Ny-Ålesund radiosonde data record have shown that the ventilation within the ABL above $\mathrm{Ny}$-Ålesund has decreased over the last two decades, as smaller wind 

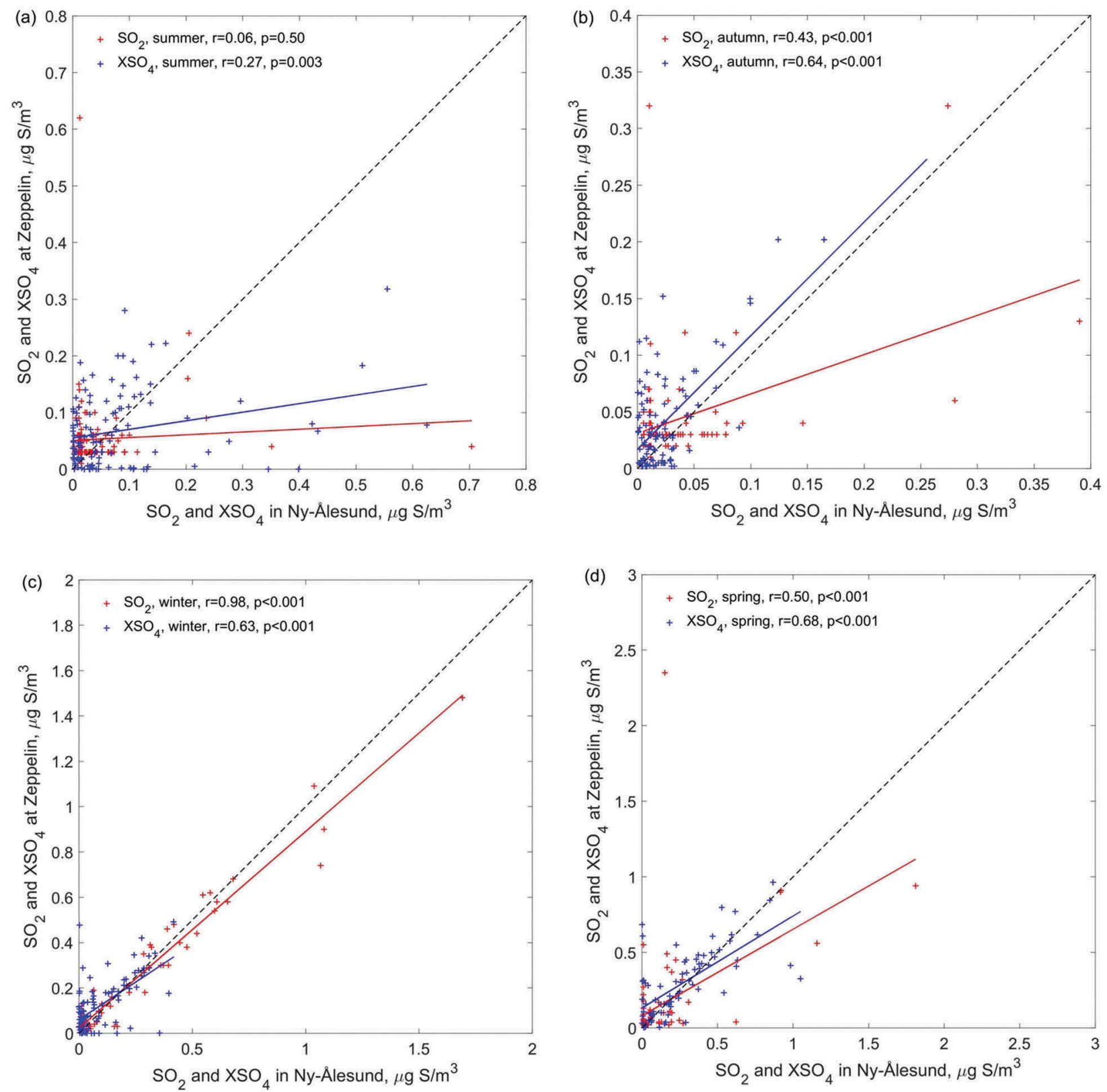

Figure 2. Seasonal $\mathrm{SO}_{2}$ and $\mathrm{XSO}_{4}{ }^{2-}$ data from Ny-Ålesund (x axes) and Zeppelin station (y axes): (a) summer; (b) autumn; (c) winter; (d) spring.

Table 2. Significant results of WRS-test $(p<0.05)$.

\begin{tabular}{|c|c|c|c|c|c|}
\hline Season & Compound and station & Factor of influence & $p$ value & $\begin{array}{l}\text { Median of the group where } \\
\text { the factor of influence is } \\
\text { absent }\left(\mu \mathrm{gS} \cdot \mathrm{m}^{-3}\right)\end{array}$ & $\begin{array}{c}\text { Median of the group where } \\
\text { the factor of influence is } \\
\text { present }\left(\mu \mathrm{gS} \cdot \mathrm{m}^{-3}\right)\end{array}$ \\
\hline \multirow[t]{4}{*}{ Summer } & \multirow[t]{2}{*}{$\mathrm{XSO}_{4}{ }^{2-}, \mathrm{Ny}$-Ålesund } & Vertical wind speed shear & $<0.01$ & 0.0510 & 0.0235 \\
\hline & & Strong humidity inversion & $<0.01$ & 0.0296 & 0.0635 \\
\hline & \multirow[t]{2}{*}{$\mathrm{SO}_{2}, \mathrm{Ny}$-Ålesund } & $\begin{array}{l}\text { Daily number of ship } \\
\text { passengers above or } \\
\text { equal to } 100\end{array}$ & 0.02 & 0.0125 & 0.0220 \\
\hline & & Vertical wind speed shear & $<0.01$ & 0.0230 & 0.0133 \\
\hline Autumn & $\mathrm{SO}_{2}, \mathrm{Ny}$-Ålesund & Temperature inversion & 0.01 & 0.0115 & 0.0120 \\
\hline Winter & $\mathrm{XSO}_{4}{ }^{2-}, \mathrm{Ny}$-Ålesund & Temperature inversion & 0.01 & 0.0292 & 0.0723 \\
\hline \multirow[t]{5}{*}{ Spring } & $\mathrm{SO}_{2}, \mathrm{Ny}$-Ålesund & Temperature inversion & 0.03 & 0.0118 & 0.0350 \\
\hline & $\mathrm{XSO}_{4}{ }^{2-}, \mathrm{Ny}$-Ålesund & & 0.01 & 0.1618 & 0.2675 \\
\hline & $\mathrm{SO}_{2}$, Zeppelin & & $<0.01$ & 0.0300 & 0.0400 \\
\hline & $\mathrm{XSO}_{4}{ }^{2-}$, Zeppelin & & $<0.01$ & 0.1390 & 0.3210 \\
\hline & $\mathrm{XSO}_{4}{ }^{2-}, \mathrm{Ny}-\mathrm{A} l e s u n d$ & Strong humidity inversion & $<0.01$ & 0.2865 & 0.1218 \\
\hline
\end{tabular}

velocities are being observed more frequently in all seasons (Maturilli \& Kayser 2016). This implies that the conditions favourable for the accumulation of pollution in the ABL may occur more often. 
(a)

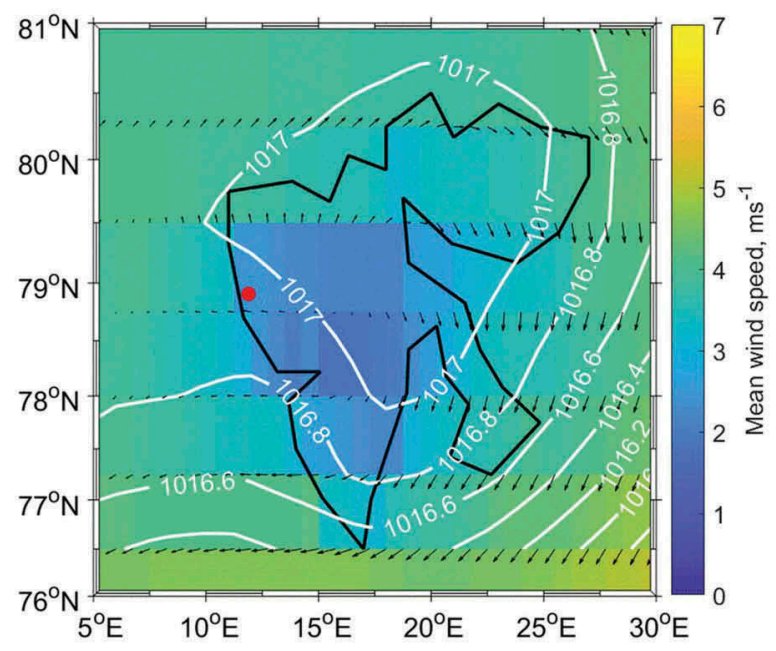

(b)

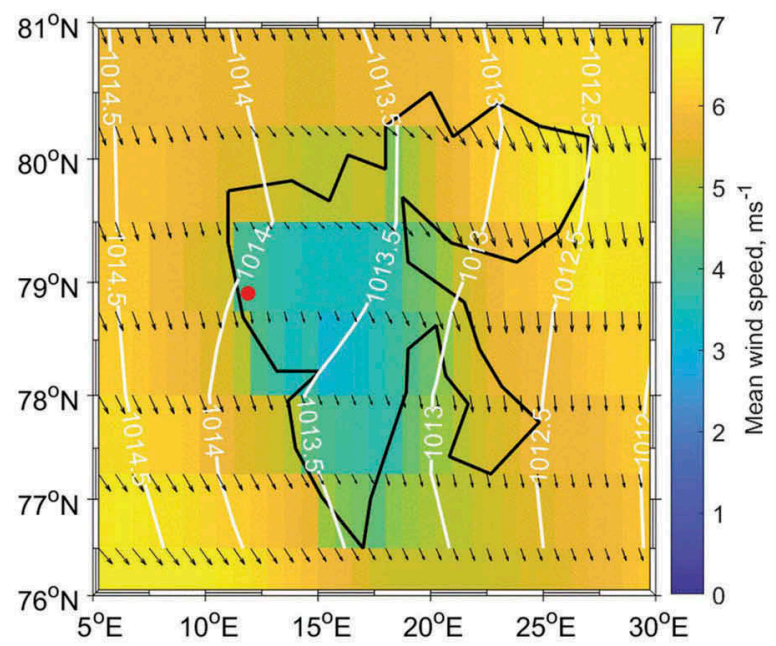

Figure 3. Summer mean wind speed in $\mathrm{m} \cdot \mathrm{s}^{-1}$ (colour scale), wind direction (black arrows with the length relative to the wind speed) and mean sea-level pressure in mbar (white lines) in the Svalbard area (black outline) and Ny-Ålesund (red dot), obtained from surface ERA-Interim data: (a) for days with strong humidity inversion; (b) for days with normal or no humidity inversion.

In order to assess influence of the ship traffic emissions on the measurements at both stations, all summer days were divided into two groups: one group with the daily number of people visiting Ny-Ålesund by ship above or equal to 100; and one group with the number of passengers below 100. The number of people is an indicator of ship size and, hence, the amount of emissions. In total, $66 \%$ of the summer data may have been impacted by pollution from the ships, since 101 out of 154 days of summer measurements belong to the first group. However, as Fig. 2 shows, summer $\mathrm{SO}_{2}$ concentrations measured at both the Zeppelin and Ny-Ålesund stations were usually much lower than in winter and spring. There may be a few reasons for this. Firstly, long-range transported pollution prevailing in the Arctic in winter and spring decreases in summer because of the change in the position of the Arctic
Front, which prevents effective south-to-north longrange air transport (AMAP 2006). Secondly, there are few local anthropogenic sources of air pollution in the Artic and some of them have intermittent emission rates, e.g., ship traffic (Dekhtyareva et al. 2016). Thirdly, the conversion rate of $\mathrm{SO}_{2}$ to $\mathrm{SO}_{4}{ }^{2-}$ increases in summer, a process governed by two major mechanisms. The first mechanism is the oxidation of gaseous $\mathrm{SO}_{2}$ by hydroxyl radical in clear-sky conditions. Studies have shown that the conversion rate increases with increasing temperature and relative humidity and is a function of Julian day (Meagher \& Bailey 1983; Eatough et al. 1994). The second mechanism is the conversion of $\mathrm{SO}_{2}$ to $\mathrm{SO}_{4}{ }^{2-}$ through various chemical reactions in the aqueous solutions in clouds and fog (Eatough et al. 1994; Seinfeld \& Pandis 2006). Despite very low average summer concentrations of $\mathrm{SO}_{2}$ measured at

the Ny-Ålesund station, there was a noticeable impact of local pollution from ships on the $\mathrm{Ny}$-Ålesund data set.

Mean $\mathrm{SO}_{2}$ values measured at the $\mathrm{Ny}$-Ålesund station for the days in the first group were almost three times higher $\left(0.05 \mu \mathrm{gS} \cdot \mathrm{m}^{-3}\right)$ than for days from the second group $\left(0.02 \mu \mathrm{gS} \cdot \mathrm{m}^{-3}\right)$, while the Zeppelin data showed almost no difference for these two groups $\left(0.05 \mu \mathrm{gS} \cdot \mathrm{m}^{-3}\right.$ vs $\left.0.06 \mu \mathrm{gS} \cdot \mathrm{m}^{-3}\right)$. This finding is supported by the WRS test that showed that median $\mathrm{SO}_{2}$ value for the first group of days in $\mathrm{Ny}$ Ålesund measurements was significantly higher than for the second one, while no difference was found for $\mathrm{SO}_{2}$ measurements at the Zeppelin station (Table 2).

Mean $\mathrm{XSO}_{4}{ }^{2-}$ values at the $\mathrm{Ny}$-Ålesund and Zeppelin stations for the first group of days ( $\geq 100$ passengers) were $50 \%$ higher $\left(0.09 \mu \mathrm{gS} \cdot \mathrm{m}^{-3}\right)$ than for the second one $\left(<100\right.$ passengers; $\left.0.06 \mu \mathrm{gS} \cdot \mathrm{m}^{-3}\right)$. This finding corresponds well with a previous study showing that at the Zeppelin station there was an 55\% increase in the number of particles with diameters characteristic of aged ship plumes, due to local pollution from ships (Dekhtyareva et al. 2016). However, the WRS test did not show a significant difference in medians for the two groups, which indicates that the sulphate measurements were infrequently affected by local pollution, but sufficiently to influence the mean value, which was increased on account of a few high concentration values.

Total daily number of passengers, indicating the size of ships, shows moderate $(r=0.38)$, but significant $(p<0.001)$, positive correlation with $\mathrm{SO}_{2}$ concentration on filters in Ny-Ålesund, while no significant correlation between these parameters has been found for the Zeppelin data set. In contrast, both the Zeppelin and $\mathrm{Ny}$-Ålesund $\mathrm{XSO}_{4}{ }^{2-}$ data sets show significant $(p=0.03)$, but weak positive correlations $(r=0.20)$ with number of passengers. A possible explanation to this is proximity to the emission source. Whether the ships were docked at the pier or anchored in the fjord, they were closer to the 
measurement station in Ny-Ålesund than to the Zeppelin station. The proximity to the source of emission is important because the oxidation from $\mathrm{SO}_{2}$ to $\mathrm{XSO}_{4}{ }^{2-}$ in aqueous and gas phases are major pathways for $\mathrm{SO}_{2}$ removal during the summertime (AMAP 2006), and therefore pollution emitted by ships may contribute to the total sulphate concentration but not to the sulphur dioxide measured at the Zeppelin station.

One may conclude that emissions from ships have an impact on both data sets in a different manner. Sulphur agents emitted by ships reach Zeppelin mostly in the oxidized form of $\mathrm{XSO}_{4}{ }^{2-}$, while the influence on measurements in the village is directly seen on the $\mathrm{SO}_{2}$ data set.

Median and mean consistent mixing layer heights were $546 \mathrm{~m}$ and $657 \mathrm{~m}$, respectively. However, only $47 \%$ of all profiles showed a mixing height higher than $474 \mathrm{~m}$. This finding supports the original argument for positioning of the Zeppelin station at the mountain top in order to prevent the influence of local pollution on measurements (Braathen et al. 1990). Furthermore, during days with little vertical mixing and strong humidity inversions below the Zeppelin station the local pollution does not reach the station, while higher concentrations were observed in the filter samples in Ny-Ålesund.

An examination of two small sub-groups of summer days serves as an example. In both groups, the mixing height was lower than $474 \mathrm{~m}$ and the daily number of ship passengers exceeded 100. The only parameter that was different is the presence of strong humidity inversions in the first group (28 days) and the absence of them in the second one (21 days). On the days in the first group, a slightly lower average wind speed was observed in $\mathrm{Ny}$-Ålesund than on the days in the second group $\left(1.6 \mathrm{~ms}^{-1}\right.$ vs $\left.2.1 \mathrm{~ms}^{-1}\right)$. The percentage of days when no cloud base was detected and when the cloud base was identified above the Zeppelin station was $39 \%$ and $18 \%$, respectively, in the first group of days, and $20 \%$ and $12 \%$ in the second one. Mean $\mathrm{XSO}_{4}{ }^{2-}$ concentrations in the first group were $0.13 \mu \mathrm{gS} \cdot \mathrm{m}^{-3}$ and $0.09 \mu \mathrm{gS} \cdot \mathrm{m}^{-3}$ at the $\mathrm{Ny}$-Ålesund and Zeppelin stations, respectively. Mean $\mathrm{XSO}_{4}{ }^{2-}$ concentrations in the second group were $0.07 \mu \mathrm{gS} \cdot \mathrm{m}^{-3}$ and $0.09 \mu \mathrm{gS} \cdot \mathrm{m}^{-3}$ at the $\mathrm{Ny}$ Ålesund and Zeppelin stations, respectively. In presence of a strong humidity inversion in the lowest $500 \mathrm{~m}$ of the ABL, concentrations in Ny-Ålesund increased, while at the Zeppelin station the average concentrations for both groups, with and without strong humidity inversion, were identical.

The processes affecting concentration distribution of aerosols are complex and depend on the particle size and parameters of the atmospheric turbulent boundary layer and the temperature inversion layer if the inversion is present (Elperin et al. 2007). For example, thermal diffusion increases near-surface concentration of coarse particles $\left(\mathrm{PM}_{10}\right)$ in inversely stratified flows over elevated terrain, while for gases and fine particles $\left(\mathrm{PM}_{2.5}\right)$ the effect is small (Sofiev et al. 2009). The shipping emissions increase concentrations of $\mathrm{SO}_{2}, \mathrm{PM}_{2.5}$ and $\mathrm{PM}_{10}$ (Viana et al. 2014). $\mathrm{PM}_{2.5}$ and gases remain in the air for a longer time after emission and may be transported over long distances from the source, while $\mathrm{PM}_{10}$ have limited spatial distribution and are often deposited downwind of the pollution sources. At the same time, sulphate may be present in both $\mathrm{PM}_{2.5}$ and $\mathrm{PM}_{10}$ (Chan et al. 1997), while $\mathrm{SO}_{2}$ oxidizes and contributes to the $\mathrm{XSO}_{4}{ }^{2-}$ concentration as well. Moreover, the processes affecting aerosol population cannot be thoroughly investigated without studying the evolution of vertical aerosol profiles (Kupiszewski et al. 2013). However, no particulate matter or vertical aerosol profiles data are available for the current study period, and the time resolution of the filter samples used in this study is too coarse to discuss the aerosol and gas processes in detail.

The WRS test showed that only $\mathrm{SO}_{2}$ measurements in $\mathrm{Ny}$-Ålesund were influenced by temperature inversions in autumn (Table 2). However, the medians for both groups were very low and quite similar. This is due to the generally very low concentration during autumn. No other statistically significant impact was revealed in autumn.

In winter, according to the WRS test, temperature inversions become an important factor increasing the median concentration in the $\mathrm{Ny}$ Ålesund $\mathrm{XSO}_{4}{ }^{2-}$ data set, but not affecting the Zeppelin station (Table 2). Change of wind direction with height and humidity inversions did not affect either of the data sets. This can be explained by low specific humidity variation with height (average standard deviation of specific humidity is $0.07 \mathrm{~g} \cdot \mathrm{kg}^{-1}$ in the lowest $500 \mathrm{~m}$ in winter versus $0.18 \mathrm{~g} \cdot \mathrm{kg}^{-1}$ in summer), low median QIS, low number of days with directional wind shear and high seasonal average median profile wind speed within the lowest $500 \mathrm{~m}\left(5.7 \mathrm{~ms}^{-1}\right)$.

In spring, in accordance with the test, temperature inversions affect $\mathrm{SO}_{2}$ and $\mathrm{XSO}_{4}{ }^{2-}$ data sets from both stations. The samples from the group of days with temperature inversions had significantly higher median values of both compounds than from the group without temperature inversions (Table 2). Average air temperature at 850 hPa was $-15^{\circ} \mathrm{C}$ and $-12^{\circ} \mathrm{C}$ in the first and second groups of days, respectively. The orientation of the wind velocity vectors and the location of the isobars in Fig. 4a show that there was a horizontal advection of colder air masses from the eastnorth-east in the first group of days, with higher concentrations. The air flow from the Arctic Ocean to the north-west of Svalbard prevailed for 

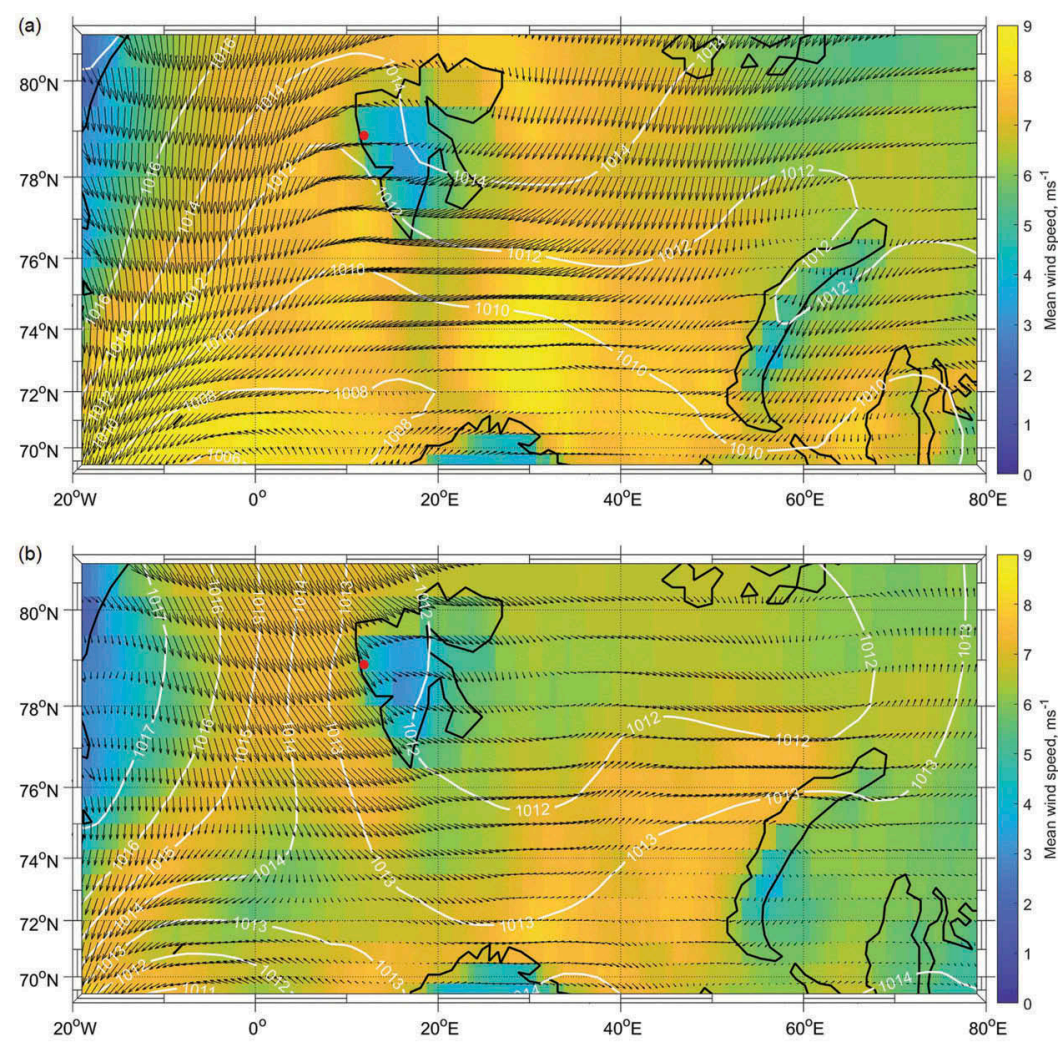

Figure 4. Spring mean wind speed in $\mathrm{m} \cdot \mathrm{s}^{-1}$ (colour scale), wind direction (black arrows with the length relative to the wind speed) and mean sea-level pressure in mbar (white lines) in the Greenland and Barents seas, obtained from surface ERA-Interim data: (a) for days with temperature inversion; (b) for days without temperature inversion.

Table 3. Mean spring concentrations in daily filter samples at the Ny-Ålesund and Zeppelin stations, $\mu \mathrm{gS} \cdot \mathrm{m}^{-3}$. The values in boldface correspond to significant results of the WRS test shown in Table 2.

\begin{tabular}{|c|c|c|c|c|c|c|c|}
\hline $\begin{array}{l}\text { Measured compound } \\
\text { and station }\end{array}$ & Seasonal & $\begin{array}{l}\text { Change in wind } \\
\text { direction }\end{array}$ & $\begin{array}{l}\text { No change in wind } \\
\text { direction }\end{array}$ & $\begin{array}{l}\text { Temperature } \\
\text { inversion }\end{array}$ & $\begin{array}{l}\text { No Temperature } \\
\text { inversion }\end{array}$ & $\begin{array}{l}\text { Strong humidity } \\
\text { inversion }\end{array}$ & $\begin{array}{c}\text { Normal or no } \\
\text { humidity inversion }\end{array}$ \\
\hline $\mathrm{SO}_{2}, \mathrm{Ny}$-Ålesund & 0.124 & 0.087 & 0.141 & 0.175 & 0.031 & 0.042 & 0.177 \\
\hline $\mathrm{XSO}_{4}{ }^{2-}, \mathrm{Ny}-\mathrm{A} l e s u n d$ & 0.270 & 0.334 & 0.239 & 0.326 & 0.169 & 0.194 & 0.320 \\
\hline $\mathrm{SO}_{2}$, Zeppelin & 0.146 & 0.133 & 0.152 & 0.200 & 0.058 & 0.082 & 0.185 \\
\hline $\mathrm{XSO}_{4}{ }^{2-}$, Zeppelin & 0.297 & 0.356 & 0.269 & 0.363 & 0.195 & 0.264 & 0.318 \\
\hline
\end{tabular}

the second group of days, with lower concentrations (Fig. 4b).

The mean spring concentrations on daily filter samples from the Ny-Ålesund and Zeppelin stations are shown in Table 3. The values for the groups for which the WRS test detected significant difference in medians are indicated. The mean spring $\mathrm{SO}_{2}$ and $\mathrm{XSO}_{4}{ }^{2-}$ values changed dramatically at both the $\mathrm{Ny}$ Ålesund and Zeppelin stations, depending on the presence or absence of strong humidity inversions. Mean spring $\mathrm{SO}_{2}$ values for days with strong humidity inversions were four times and two times lower at the $\mathrm{Ny}$-Ålesund station and at the Zeppelin station, respectively, than mean $\mathrm{SO}_{2}$ values for the days when no strong humidity inversions were observed. Mean spring $\mathrm{XSO}_{4}{ }^{2-}$ values for the first group of days were $65 \%$ and 17\% lower at the Ny-Ålesund and Zeppelin stations, respectively, than the mean value for the days without strong humidity inversions. However, the magnitude of the reduction of the $\mathrm{SO}_{2}$ and $\mathrm{XSO}_{4}{ }^{2-}$ concentrations suggests that these conditions affect measurements at the Ny-Ålesund station more than at the Zeppelin station. Indeed, according to the test, the median $\mathrm{XSO}_{4}{ }^{2-}$ values in the Ny-Ålesund station data are significantly lower for the group of days with strong humidity inversions, while no difference was found in the data from the Zeppelin station. Strong humidity inversions have the opposite effect on filter measurement results to the one from temperature inversions. This may be explained by the different origin of air masses. Strong humidity inversions were observed when the wind direction at 850 $\mathrm{hPa}$ was from the south and west and the average air temperature at that pressure level was $-11.3^{\circ} \mathrm{C}$, while for the days with no strong humidity inversions it was $-15^{\circ} \mathrm{C}$. Figure $5 \mathrm{a}$ shows that there was a transport of warmer and more humid air from the Atlantic Ocean south of Svalbard during the days with strong humidity inversions. Prevailing weather conditions at $850 \mathrm{hPa}$ for the days with strong humidity inversions correspond very well with the ones described by Vihma et al. (2011), who characterized the effect of 

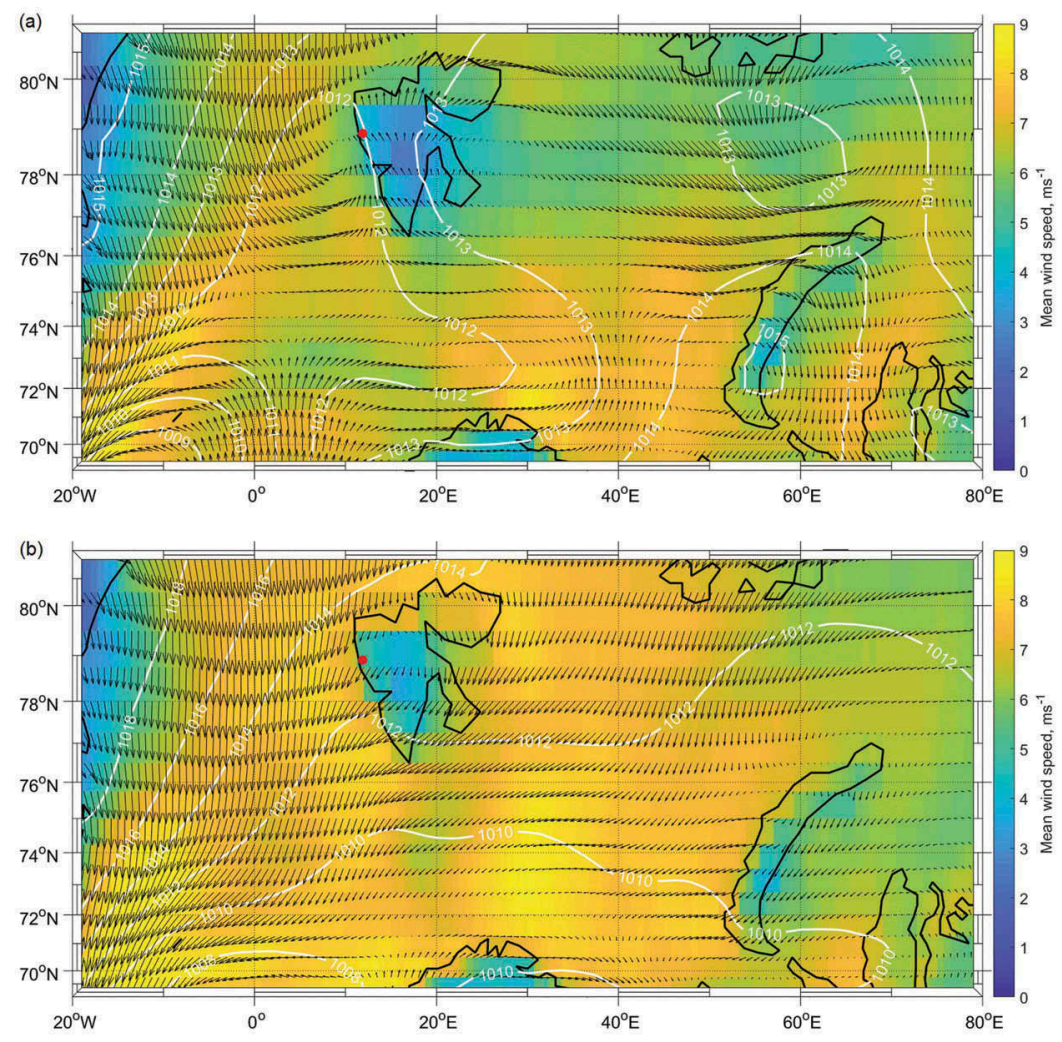

Figure 5. Spring mean wind speed in $\mathrm{m} \cdot \mathrm{s}^{-1}$ (colour scale), wind direction (black arrows with the length relative to the wind speed) and mean sea level pressure in mbar (white lines) in the Greenland and Barents seas, obtained from surface ERA-Interim data: (a) for days with strong humidity inversion; (b) for days without strong humidity inversion.

warm and humid air masses from the marine sector $\left(200-290^{\circ}\right)$ on the formation of humidity inversions. In contrast, the location of isobars in Fig. 5b for the group without strong humidity inversions was similar to the one for the group of days with temperature inversions (Fig. 4a), indicating the transport of colder air masses with higher concentrations of sulphur compounds from the east. Moreover, the temperature at the level of $850 \mathrm{hPa}$ correlates differently with temperature and humidity inversion strengths in spring. There is a statistically significant negative correlation between TIS $(\mathrm{r}=-0.30, p=0.004)$ and the air temperature at $850 \mathrm{hPa}$, while the correlation with QIS is positive $(\mathrm{r}=0.26, p=0.01)$. This indicates that strong humidity inversions are caused by the horizontal transport of warmer air masses and not by the radiative cooling of the surface layer. Lower concentration of $\mathrm{XSO}_{4}{ }^{2-}$ in $\mathrm{Ny}$-Ålesund than at the Zeppelin station may be explained by the fact that the air masses are of marine nature, and the deposition velocities above the air-water interface may be slightly higher compared with deposition to dry surfaces because of growth of hygroscopic particles in the humid boundary layer (Seinfeld \& Pandis 2006).

A main weakness in this study is the filter-sampling method, which affects the number of values below the detection limit, and consequently the correlation between the data sets. As Aas et al. (2007) stated, the reference European Monitoring and Evaluation
Programme method, based on the use of potassium hydroxide-impregnated filters for $\mathrm{SO}_{2}$ detection, is not well suited to monitoring low background concentrations because of its high detection limit. The seasonal percentage of $\mathrm{SO}_{2}$ values below the detection limit $\left(\mathrm{L}_{\mathrm{d}}\right)$ in the data sets at both stations is very high irrespective of the season, while the percentage is lower in the $\mathrm{XSO}_{4}{ }^{2-}$ data set (Table 4). The rate of missing data in the Ny-Ålesund station data set is higher than in the Zeppelin data set in all seasons.

Another uncertainty is related to the fact that only one radiosounding per filter measurement was utilized in the data analysis. This gives the information about the atmospheric stratification and vertical wind profile at the time of launching (generally at 12 UTC), but does not describe the profile evolution during the day. However, as one can see in Fig. 6 the lowest correlation between daily averaged temperature measurements at the Ny-Ålesund and Zeppelin stations were observed during summer. This points to a higher rate of non-linearity in interrelation between temperatures at the Ny-Ålesund and Zeppelin stations and, consequently, reflects complexity of the processes in the ABL. In general, the atmospheric lapse rate is formed under the combination of convection and radiation processes (Wallace \& Hobbs 2006); however, we have seen from the high variation of specific humidity and frequently observed directional wind shear and clouds in 
Table 4. Characteristics of the filter data sets.

\begin{tabular}{|c|c|c|c|c|c|c|}
\hline \multirow[b]{2}{*}{ Station } & \multirow[b]{2}{*}{ Characteristic } & \multirow[b]{2}{*}{ Compound } & \multicolumn{4}{|c|}{ Season } \\
\hline & & & $\begin{array}{c}\text { summer } \\
(\mathrm{n}=154)\end{array}$ & $\begin{array}{l}\text { autumn } \\
(\mathrm{n}=182)\end{array}$ & $\begin{array}{c}\text { winter } \\
(n=121)\end{array}$ & $\begin{array}{c}\text { spring } \\
(\mathrm{n}=92)\end{array}$ \\
\hline \multirow[t]{2}{*}{ Ny-Ålesund } & Rate of values below $L_{d}(\%)$ & $\mathrm{SO}_{2}$ & 45 & 42 & 45 & 43 \\
\hline & & $\mathrm{XSO}_{4}{ }^{2-}$ & 31 & 41 & 35 & 10 \\
\hline \multirow[t]{2}{*}{ Zeppelin } & Rate of values below $L_{d}(\%)$ & $\mathrm{SO}_{2}$ & 45 & 54 & 40 & 49 \\
\hline & & $\mathrm{XSO}_{4}{ }^{2-}$ & 21 & 32 & 17 & 14 \\
\hline Ny-Ålesund & Rate of missing data (\%) & $\mathrm{SO}_{2}$ and $\mathrm{XSO}_{4}{ }^{2-}$ & 21 & 32 & 17 & 14 \\
\hline Zeppelin & Rate of missing data (\%) & $\mathrm{SO}_{2}$ and $\mathrm{XSO}_{4}^{2-}$ & 1 & 14 & 6 & 3 \\
\hline
\end{tabular}

(a)
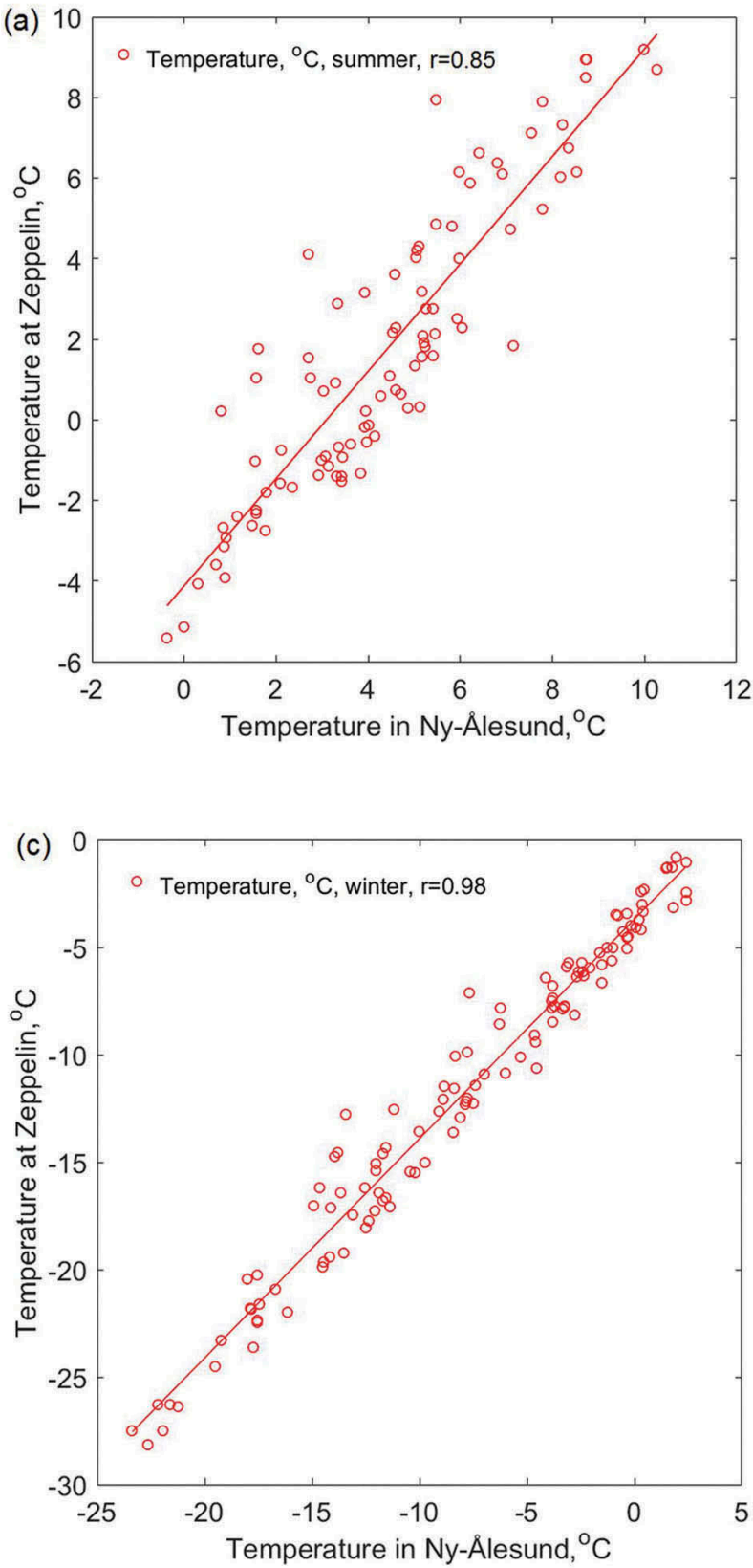

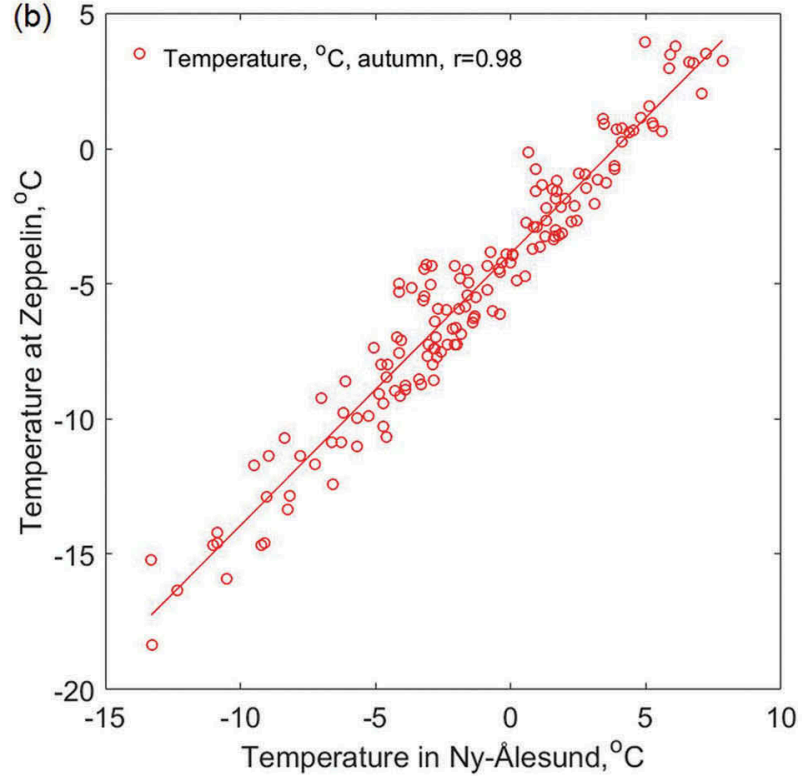

(d)

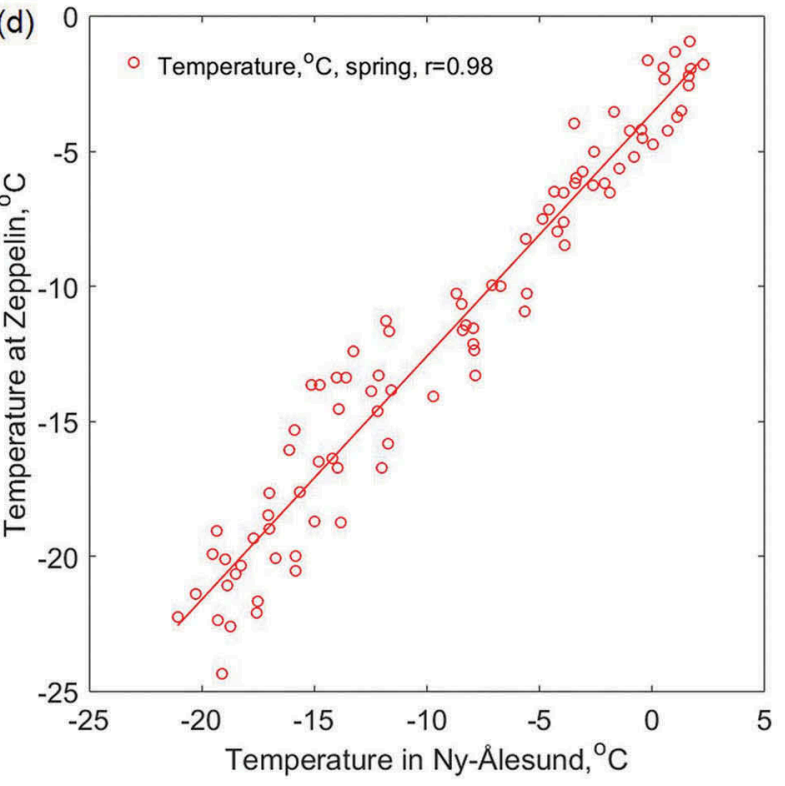

Figure 6. Seasonal plots of daily averaged air temperature measured at the Ny-Ålesund and Zeppelin stations: (a) summer; (b) autumn; (c) winter; (d) spring.

summer profiles that there have been air flows with quite different characteristics in the lowest $500 \mathrm{~m}$. Interaction of these flows and radiation processes within the clouds may influence the correlation of daily temperature measured at the two stations, so the characteristics of the profiles are not only instantaneous features of the $\mathrm{ABL}$, but are important for the lapse rate formation throughout the day in summer.

The findings presented in this paper may be relevant for planning future fieldwork campaigns and comparing modelling results with measurements 
done in a region with complex topography, such as the Ny-Ålesund area. Knowledge of the micrometeorological conditions of the study area is crucial if one wants to eliminate local effects by choosing the right location for the station or to contrast results from already existing stations situated close to each other. For comparison of historical data with modelling results, one needs to investigate local meteorological factors that may affect measurement results and choose the model resolution that correctly represents these factors. A study by Mölders et al. (2011) has shown that the combined chemical and meteorological model WRF-Chem with a resolution of $4 \mathrm{~km}$ tends to underestimate the inversion strengths, presents biases of temperature and wind speed and determines incorrect wind direction at low wind speeds. Furthermore, it has been stated that errors in modelled temperatures may lead to erroneous modelled concentrations of aerosols (Mölders et al. 2011). As there is a trade-off between the resolution and the computational time in the model, it is useful to know if the measurement results from the station are subject to a significant impact of local pollution and/or micrometeorological factors. This can be checked using the statistical methods applied in this article.

\section{Conclusion}

The correlation of daily sulphur dioxide $\left(\mathrm{SO}_{2}\right)$ and non-sea salt sulphate $\left(\mathrm{XSO}_{4}{ }^{2-}\right)$ data sets from the $\mathrm{Ny}$-Ålesund station and the Zeppelin mountain station has a large seasonal variation. No significant correlation between the $\mathrm{SO}_{2}$ data sets has been observed in the summer data, while a very strong correlation is present in the winter data, with autumn and spring showing intermediate to moderate values of Pearson correlation coefficient. Although the correlation between the $\mathrm{XSO}_{4}{ }^{2-}$ data sets is significant for all times of year, it is much lower for the summer data compared to other seasons.

The first hypothesis, stating the significance of the effect of temperature and humidity inversions on the correspondence between the data sets from the $\mathrm{Ny}$ Ålesund and Zeppelin stations, is supported. In winter, concentration of $\mathrm{XSO}_{4}{ }^{2-}$ at the Ny-Ålesund station is significantly higher in the days with temperature inversions, while in spring this effect is seen in data sets from both stations. Local meteorological conditions on the days with strong humidity inversions reduce and increase the sulphate concentration at the Ny-Ålesund station in spring and summer, respectively.

The second hypothesis has been rejected, since the directional shear appeared to be an insignificant factor, while the third hypotheses about the influence of wind speed shear on the correspondence of measurements is relevant only for the summer season. In the absence of the wind speed shear, local pollution affects Ny-Ålesund sulphur dioxide and sulphate data set more strongly.

The fourth hypothesis, stating the effect of local summertime emissions from ship traffic on the correspondence between the data sets from the two stations, is partially supported. Local summertime ship traffic has a strong impact on the $\mathrm{SO}_{2} \mathrm{Ny}$-Ålesund data set, while there is no statistically significant effect on the Zeppelin data set. The $\mathrm{XSO}_{4}{ }^{2-}$ data sets at both stations are impacted by pollution from ships, but the influence on the Ny-Ålesund data set is more pronounced on days with strong humidity inversions.

The findings presented here are highly important for planning joint monitoring campaigns and the exchange and comparison of measurement results in Ny-Ålesund. Both anthropogenic factors, such as local pollution in summer, and natural ones, namely local circulation patterns and variation of temperature and humidity in the ABL, affect the correspondence between the data sets collected at the locations within the range of $2 \mathrm{~km}$. Furthermore, the nature of the sulphur species studied here determines which factors affected the concentration of the measured compounds at the two stations.

The environmental phenomena described here still represent a challenge for modellers and need to be taken into account when comparing modelling results with in situ measurements taken at different heights in an area with complex topography.

\section{Acknowledgements}

The Norwegian Polar Institute is acknowledged for the detailed map of Svalbard available at http://svalbardkartet. npolar.no. Special thanks are given to the Norwegian Polar Institute for the support and coordination of research activities in Ny-Ålesund, which become a basis for this paper. The European Centre for Medium-Range Weather Forecasts is acknowledged for data from the ERA-Interim global atmospheric reanalysis data set used in the present work. Dr Kåre Edvardsen is thanked for reviewing this manuscript. The authors would like to thank Dr John J. Cassano and two anonymous reviewers for thorough reading of the manuscript, constructive comments and suggestions, which helped to improve the quality of the paper.

\section{Disclosure statement}

No potential conflict of interest was reported by the authors.

\section{Funding}

The filter sample measurements were done within the framework of the project Monitoring of Local Air Quality in Ny-Ålesund 2008-2010, supported by the Norwegian 
Institute for Air Research, the Norwegian Polar Institute and the Svalbard Environmental Protection Fund. The authors also gratefully acknowledge support for the NyÅlesund radiosonde data from the Transregional Collaborative Research Center (TR 172), specifically the project Arctic Amplification: Climate Relevant Atmospheric and Surface Processes, and Feedback Mechanisms (AC)3, which is funded by the German Research Foundation (Deutsche Forschungsgemeinschaft).

\section{ORCID}

Alena Dekhtyareva (D) http://orcid.org/0000-0003-41627427

Marion Maturilli (D) http://orcid.org/0000-0001-6818-7383

\section{References}

Aas W., Schaug J. \& Hanssen J.E. 2007. Field intercomparison of main components in air in EMEP. Water Air \& Soil Pollution: Focus 7, 25-31.

AMAP 2006. AMAP assessment 2006: acidifying pollutants, Arctic haze, and acidification in the Arctic. Oslo: Arctic Monitoring and Assessment Programme.

Anfossi D., Oettl D. \& Degrazia G.A. 2004. Some aspects of turbulence and dispersion in low wind speed conditions. In C. Borrego \& S. Incecik (eds.): Air pollution modeling and its application XVI. Pp. 331-338. Boston: Springer.

Beine H.J., Engardt M., Jaffe D.A., Hov Ø., Holmén K. \& Stordal F. 1996. Measurements of $\mathrm{NO}_{\mathrm{x}}$ and aerosol particles at the $\mathrm{Ny}$-Ålesund Zeppelin mountain station on Svalbard: influence of regional and local pollution sources. Atmospheric Environment 30, 1067-1079.

Bolton D. 1980. The computation of equivalent potential temperature. Monthly Weather Review 108, 1046-1053.

Braathen G.O., Hov Ø. \& Stordal F. 1990. Arctic atmospheric research station on the Zeppelin mountain (474 $\mathrm{m}$ a.s.l.) near Ny-Ålesund on Svalbard (78 $\left.54^{\prime} 29^{\prime \prime} N, 11^{\circ} 52^{\prime} 53^{\prime \prime} E\right)$. Lillestrøm: Norwegian Institute for Air Research.

Chan Y.C., Simpson R.W., Mctainsh G.H., Vowles P.D., Cohen D.D. \& Bailey G.M. 1997. Characterisation of chemical species in $\mathrm{PM}_{2.5}$ and $\mathrm{PM}_{10}$ aerosols in Brisbane, Australia. Atmospheric Environment 31, 3773-3785.

Chernokulsky A.V., Esau I., Bulygina O.N., Davy R., Mokhov I.I., Outten S. \& Semenov V.A. 2017. Climatology and interannual variability of cloudiness in the Atlantic Arctic from surface observations since the late nineteenth century. Journal of Climate 30, 2103-2120.

Dee D.P., Uppala S.M., Simmons A.J., Berrisford P., Poli P., Kobayashi S., Andrae U., Balmaseda M.A., Balsamo G., Bauer P., Bechtold P., Beljaars A.C.M., van de Berg L., Bidlot J., Bormann N., Delsol C., Dragani R., Fuentes M., Geer A.J., Haimberger L., Healy S.B., Hersbach H., Hólm E.V., Isaksen L., Kållberg P., Köhler M., Matricardi M., McNally A.P., Monge-Sanz B.M., Morcrette -J.-J., Park B.-K., Peubey C., de Rosnay P., Tavolato C., Thépaut J.N. \& Vitart F. 2011. The ERA-Interim reanalysis: configuration and performance of the data assimilation system. Quarterly Journal of the Royal Meteorological Society 137, 553-597.

Dekhtyareva A., Edvardsen K., Holmén K., Hermansen O. \& Hansson H.-C. 2016. Influence of local and regional air pollution on atmospheric measurements in Ny-Ålesund.
International Journal of Sustainable Development and Planning 11, 578-587.

Eatough D.J., Caka F.M. \& Farber R.J. 1994. The conversion of $\mathrm{SO}_{2}$ to sulfate in the atmosphere. Israel Journal of Chemistry 34, 301-314.

Eckhardt S., Hermansen O., Grythe H., Fiebig M., Stebel K., Cassiani M., Baecklund A. \& Stohl A. 2013. The influence of cruise ship emissions on air pollution in Svalbard-a harbinger of a more polluted Arctic? Atmospheric Chemistry and Physics 13, 8401-8409.

Elperin T., Kleeorin N., Liberman M.A., L’vov V.S. \& Rogachevskii I. 2007. Clustering of aerosols in atmospheric turbulent flow. Environmental Fluid Mechanics 7, 173-193.

EPA 2000. Meteorological monitoring guidance for regulatory modeling applications. EPA-454/R-99-005. Research Triangle Park, NC: US Environmental Protection Agency.

Esau I. \& Repina I. 2012. Wind climate in Kongsfjorden, Svalbard, and attribution of leading wind driving mechanisms through turbulence-resolving simulations. Advances in Meteorology 2012, article no. 568454, doi: $10.1155 / 2012 / 568454$.

Ferrero L., Cappelletti D., Busetto M., Mazzola M., Lupi A., Lanconelli C., Becagli S., Traversi R., Caiazzo L., Giardi F., Moroni B., Crocchianti S., Fierz M., Močnik G., Sangiorgi G., Perrone M.G., Maturilli M. \& Vitale V. 2016. Vertical profiles of aerosol and black carbon in the Arctic: a seasonal phenomenology along 2 years (20112012) of field campaigns. Atmospheric Chemistry and Physics 16, 12601-12629.

Fisher B. 2002. Meteorological factors influencing the occurrence of air pollution episodes involving chimney plumes. Meteorological Applications 9, 199-210.

Hermansen O., Wasseng J., Bäcklund A., Noon B., Hennig T., Schulze D. \& Barth V.L. 2011. Air quality NyÅlesund. Monitoring of local air quality 2008-2010. Measurement results. Kjeller: Norwegian Institute for Air Research.

Hodal H., Falk-Petersen S., Haakon H., Kristiansen S. \& Reigstad M. 2012. Spring bloom dynamics in Kongsfjorden, Svalbard: nutrients, phytoplankton, protozoans and primary production. Polar Biology 35, 191-203.

Keller M.D., Bellows W.K. \& Guillard R.R.L. 1989. Dimethyl sulfide production in marine phytoplankton. In E.S. Saltzman \& W.J. Cooper (eds.): Biogenic sulfur in the environment. Pp. 167-182. Washington D.C.: American Chemical Society.

Krzywinski M. \& Altman N. 2014. Points of significance: nonparametric tests. Nature Methods 11, 467-469.

Kupiszewski P., Leck C., Tjernström M., Sjogren S., Sedlar J., Graus M., Müller M., Brooks B., Swietlicki E., Norris S. \& Hansel A. 2013. Vertical profiling of aerosol particles and trace gases over the central Arctic Ocean during summer. Atmospheric Chemistry and Physics 13, 12405-12431.

Levasseur M. 2013. Impact of Arctic meltdown on the microbial cycling of sulphur. Nature Geoscience 6, 691-700.

Liang J. \& Jacobson M.Z. 1999. A study of sulfur dioxide oxidation pathways over a range of liquid water contents, $\mathrm{pH}$ values, and temperatures. Journal of Geophysical Research-Atmospheres 104, 13749-13769.

Markowski P. \& Richardson Y. 2006. On the classification of vertical wind shear as directional shear versus speed shear. Weather and Forecasting 21, 242-247.

Matsumura S., Zhang X. \& Yamazaki K. 2014. Summer Arctic atmospheric circulation response to spring 
Eurasian snow cover and its possible linkage to accelerated sea ice decrease. Journal of Climate 27, 6551-6558.

Maturilli M., Herber A. \& König-Langlo G. 2013. Climatology and time series of surface meteorology in Ny-Ålesund, Svalbard. Earth System Science Data 5, 155-163.

Maturilli M. \& Kayser M. 2016. Arctic warming, moisture increase and circulation changes observed in the $\mathrm{Ny}$ Ålesund homogenized radiosonde record. Theoretical and Applied Climatology 130, 1-17.

Meagher J.F. \& Bailey E.M. 1983. The seasonal variation of the atmospheric $\mathrm{SO}_{2}$ to $\mathrm{SO}_{4}{ }^{2-}$ conversion rate. Journal of Geophysical Research-Oceans 88, 1525-1527.

Mölders N., Tran H.N.Q., Quinn P., Sassen K., Shaw G. E. \& Kramm G. 2011. Assessment of WRF/Chem to simulate sub-Arctic boundary layer characteristics during low solar irradiation using radiosonde, SODAR, and surface data. Atmospheric Pollution Research 2, 283-299.

Moroni B., Becagli S., Bolzacchini E., Busetto M., Cappelletti D., Crocchianti S., Ferrero L., Frosini D., Lanconelli C., Lupi A., Maturilli M., Mazzola M., Perrone M.G., Sangiorgi G., Traversi R., Udisti R., Viola A. \& Vitale V. 2015. Vertical profiles and chemical properties of aerosol particles upon Ny-Ålesund (Svalbard islands). Advances in Meteorology, article no. 292081, doi: 10.1155/2015/292081.

NILU 1996. EMEP manual for sampling and chemical analysis. EMEP/CCC-report 1/95. Kjeller: Norwegian Institute for Air Research.

Norwegian Polar Institute. 2016. Report from the NyÅlesund Seminar. Tromsø, Norway, 23-25 September 2015. Tromsø: Norwegian Polar Institute.

Nygård T., Valkonen T. \& Vihma T. 2014. Characteristics of Arctic low-tropospheric humidity inversions based on radio soundings. Atmospheric Chemistry and Physics 14, 1959-1971.

Orr C., Hurd F.K. \& Corbett W.J. 1958. Aerosol size and relative humidity. Journal of Colloid Science 13, 472-482.

Quinn P.K., Shaw G., Andrews E., Dutton E.G., RuohoAirola T. \& Gong S.L. 2007. Arctic haze: current trends and knowledge gaps. Tellus B 59, 99-114.

Seinfeld J.H. \& Pandis S.N. 2006. Atmospheric chemistry and physics: from air pollution to climate change. 2nd edn. New York: John Wiley \& Sons
Seuthe L., Iversen K.R. \& Narcy F. 2011. Microbial processes in a high-latitude fjord (Kongsfjorden, Svalbard): II. Ciliates and dinoflagellates. Polar Biology 34, 751-766.

Shikai C., Jianfeng H., Peimin H., Fang Z., Ling L. \& Yuxin M. 2012. The adaptation of Arctic phytoplankton to low light and salinity in Kongsfjorden (Spitsbergen). Advances in Polar Science 23, 19-24.

Sofiev M., Sofieva V., Elperin T., Kleeorin N., Rogachevskii I. \& Zilitinkevich S.S. 2009. Turbulent diffusion and turbulent thermal diffusion of aerosols in stratified atmospheric flows. Journal of Geophysical Research Atmospheres-Atmospheres 114, D18209, doi: 10.1029/ 2009JD011765.

Stull R.B. 1988. An introduction to boundary layer meteorology. Dordrecht, The Netherlands: Kluwer Academic Publishers.

Viana M., Hammingh P., Colette A., Querol X., Degraeuwe B., de Vlieger I. \& van Aardenne J. 2014. Impact of maritime transport emissions on coastal air quality in Europe. Atmospheric Environment 90, 96-105.

Vihma T., Kilpeläinen T., Manninen M., Sjöblom A., Jakobson E., Palo T., Jaagus J. \& Maturilli M. 2011. Characteristics of temperature and humidity inversions and low-level jets over Svalbard fjords in spring. Advances in Meteorology, article no. 486807 , doi: 10.1155/2011/486807.

Walcek C.J. 2002. Effects of wind shear on pollution dispersion. Atmospheric Environment 36, 511-517.

Wallace J.M. \& Hobbs P.V. 2006. Atmospheric science: an introductory survey. 2nd edn. New York: Academic Press.

Wang X.Y. \& Wang K.C. 2014. Estimation of atmospheric mixing layer height from radiosonde data. Atmospheric Measurement Techniques 7, 1701-1709.

Yin F., Grosjean D. \& Seinfeld J.H. 1990. Photooxidation of dimethyl sulfide and dimethyl disulfide. I: mechanism development. Journal of Atmospheric Chemistry 11, 309-364.

Yoch D.C. 2002. Dimethylsulfoniopropionate: its sources, role in the marine food web, and biological degradation to dimethylsulfide. Applied and Environmental Microbiology 68, 5804-5815. 